\title{
Ostracods and foraminifera from the Early - Middle Eocene of Qeren Sartaba, Jordan Valley
}

\author{
A. HONIGSTEIN ${ }^{1}$, A. ROSENFELD ${ }^{2} \&$ C. BENJAMINI ${ }^{3}$ \\ 1. Dept. of Geophysics and Planetary Sciecnes, Tel Aviv University \\ 2. Geological Survey of Israel, Jerusalem \\ 3.Dept. of Geology, Ben Gurion University of the Negev, Beer Sheva
}

\begin{abstract}
- 23 species of ostracods and 20 species and species groups of planktonic foraminifera from the $80 \mathrm{~m}$ thick Qeren Sartabasection, central Jordan Valley, are described and illustrated. The material is determined by planktonic foraminiferal biostratigraphy to belong to the latest Early Eocene (upper part of Zone P9) and the early Middle Eocene (Zone PI0). The palaeoecology is representative of a pelagic marine shelf, with periodic events of shallowing and hardground formation.
\end{abstract}

\section{INTRODUCTION AND GEOLOGICAL SETTING}

The Eocene section in the Qeren Sartaba region, central Jordan Valley, eastern Samaria (Fig.1) was mapped and described by Benjamini (1973). This marine sequence is characterized by chalk, chert and limestone lithologies. Shallow water limestones with larger foraminifera interfinger with more pelagic, chalky lithofacies in a complex pattern, but generally trending towards pelagic predominance southwards. Part of the palaeotopography of the Eocene substrate was derived from Cretaceous tectonics (Mimran, 1984), but much resulted from intra-Eocene folding and normal faulting. Two important angular unconformities, in the late Early Eocene and the mid-Middle Eocene part of the section, are tangible evidence of this structural activity. Biostratigraphic dating of the sedimentary and structural events was by planktonic foraminifera from the chalky facies, and this material has to date not been published.

The Sartaba Member of the Matred Formation (note: lithostratigraphic nomenclature in this area is tentative and unpublished, following broadly names used in the northern Negev, southern Israel) contains an important chalk horizon with a rich assemblage of planktonic foraminifera and ostracods, characteristic of the Early - Middle Eocene transition. The section described here is located at coordinates 1937/1668 (Israeli grid), a few hundred metres south of the archaeological site of Qeren Sartaba. An additional section, approximately one kilometre west of the Sartaba section at $\Delta 278$ (coordinates $1925 / 1666$ ). The location of these sections is shown in Fig.1. Samples from the chalky horizons were taken approximately every three metres.

The Sartaba Member at the Qeren Sartaba section is $80 \mathrm{~m}$ thick, and consists of chalk and fine-grained limestone (Fig.2). The formation commences with the first chalk above the limestone Masua Member, and rapidly becomes a massive chalk, punctuated by some limestone hardgrounds. There is some limonite staining. At the interval from $50-65 \mathrm{~m}$, round nodules containing barite are present in the chalk. At $65 \mathrm{~m}$ above the base, fine-grained limestone with chalky interbeds again predominates, and the section is truncated by an angular unconformity at $80 \mathrm{~m}$. At the location at $\Delta 278$, the section is $110 \mathrm{~m}$ thick, with the additional section attributable to less truncation beneath the unconformity, as the lower subunits are identical with those of the

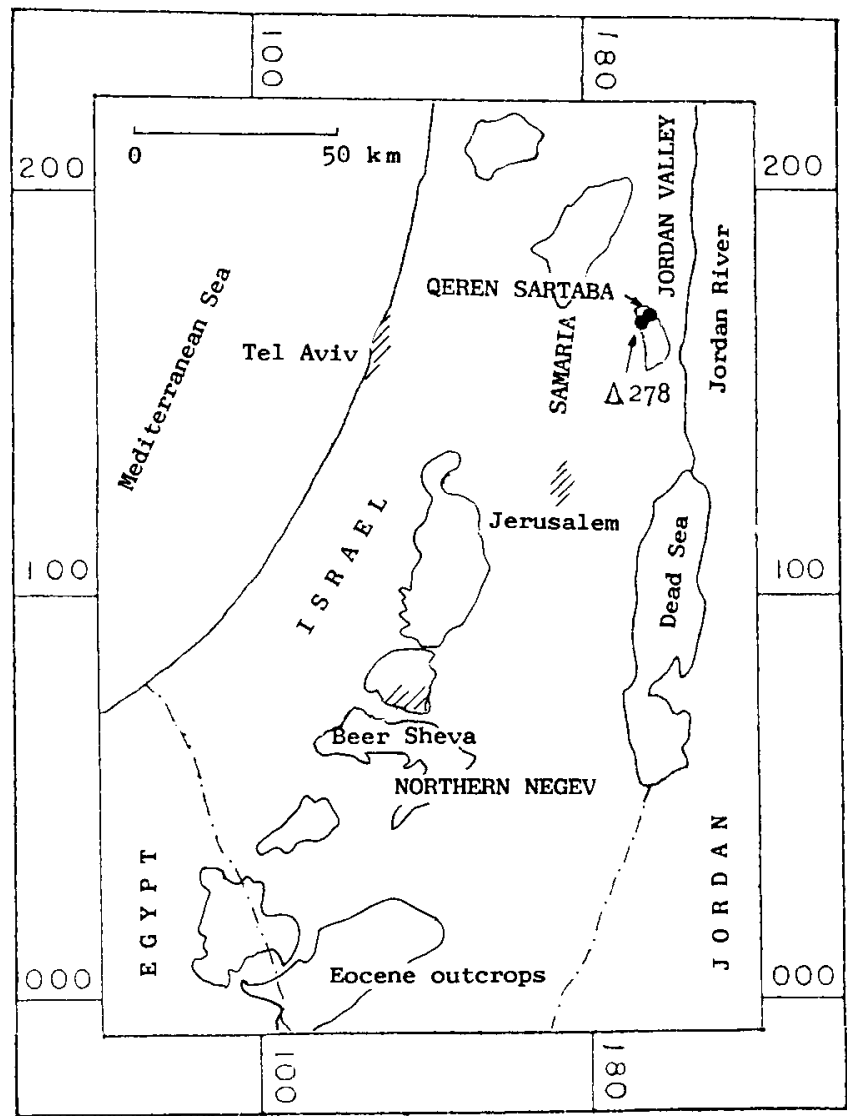

Figure 1. Location

Qeren Sartaba section.

Rare macrofossils in the chalk include small, branching (probably ahermatypic) hexacorals, a scaphopod, lucinid and cardiid bivalves, a cerithiid gastropod, and teeth of Lamna. Thin sections show the chalky facies to be a pelagic biomicrite, with abundant planktonic foraminifera and rare radiolarians. Phosphatic fragments are not uncommon. The limestone horizons 


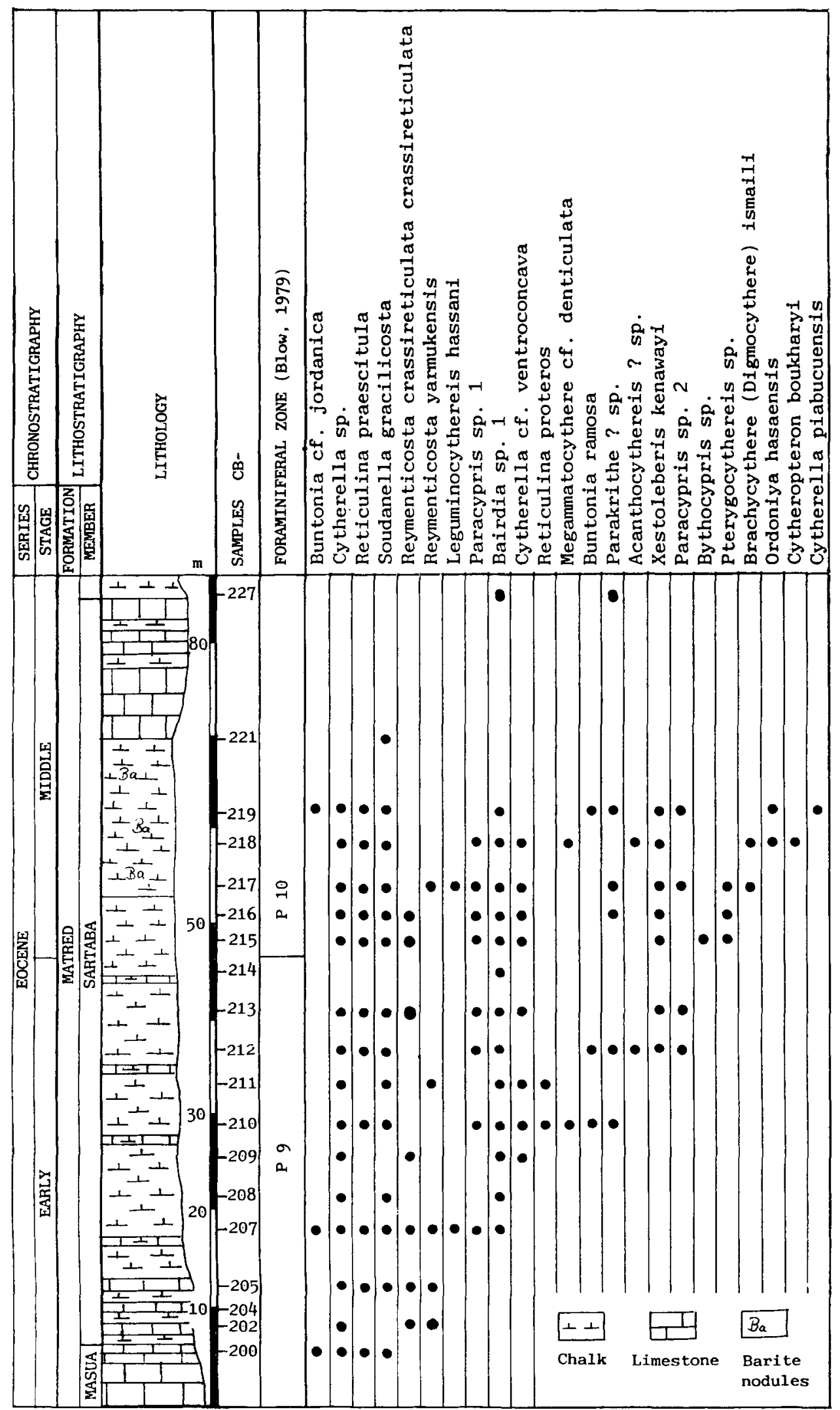

Fig. 2. Distribution chart of ostracods of the Early - Middle Eocene section at Qeren Sartaba, Jordan Valley. 


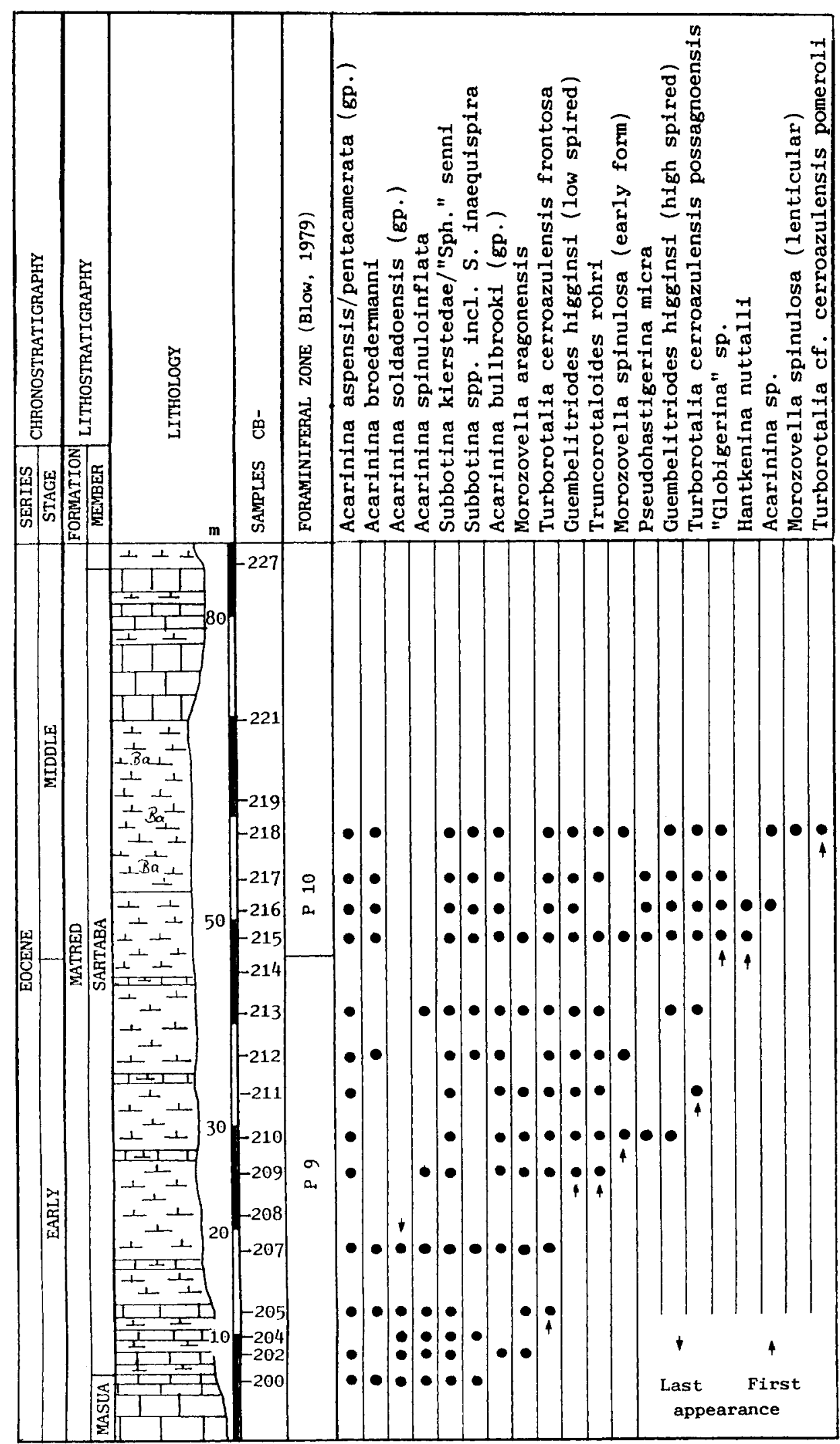

Fig. 3. Distribution chart of planktonic foraminifera of the Early - Middle Eocene section at Qeren Sartaba, Jordan Valley. 
are mostly similar, but with more evidence of bioturbation and thus probably indurated hardgrounds of the chalky facies. Ammobaculites sp. is common in the hardgrounds. At location $\Delta$ 278 , a hardground horizon at $35 \mathrm{~m}$ is colonized by a nummulitic fauna, echinid and bryozoan debris, and rhodophyceans. This fauna was not recovered from hardgrounds at this level at the Sartaba section. The limestones at the top of the Sartaba Member contain, in addition to bioturbated pelagic material, transported fragments of rotaliid larger foraminifera, foretelling a significant shallowing trend. No clastics were found in thin sections.

The palaeoenvironmental interpretation based also on field and petrographic studies is a deep neritic, subphotic shelf dominated by pelagic facies, interrupted at intervals by hardground formation. At least one of these bears evidence locally of shallowing into the photic zone. Water depths of 50-150m, of normal salinity, and relatively warm temperatures are thus indicated.

In this paper we describe an ostracod and foraminiferal faunule found at the Qeren Sartaba section.

\section{OSTRACODS}

\section{(A. Honigstein \& A. Rosenfeld)}

Eocene ostracods from Israel have not yet been described. However, Middle and Late Eocene ostracods from Jordan and Egypt were reported by Bassiouni (1969a, 1969b, 1969c, 1969d, 1971a, 1971b), Khalifa \& Cronin (1978), Cronin \& Khalifa (1979), Boukhary et al (1982b) and Bassiouni et al. (1982). Palaeocene to Early Eocene ostracods were described from Tunisia (Esker, 1968; Donze et al., 1982), Libya (Salahi, 1966), Egypt (Boukhary et al., 1982a; Bassiouni \& Luger, 1990) and Saudi Arabia (Al-Furaih, 1983). A Ph.D. thesis on Eocene ostracods from Egypt is currently being carried out by Ismail A. under the superivision of $J$. Szczechura, Institute of Paleobiology, Polish Academy of Sciences, Warszaw. Information from this thesis was also used for comparison with our material.

Common to abundant ostracod faunas were found in the Sartaba Member at Qeren Sartaba in nearly all samples of the lower and middle part of the Sartaba Member (CB200 -219). Richest in ostracods are the samples CB 215 - 218 from the middle part of the section. The ostracods are figured on Pls 1-2, and their distribution is given on Fig.2.

\section{TAXONOMY}

All the examined and described ostracods are deposited in the collection of the Geological Survey of Israel. The abbreviations $1, \mathrm{~h}, \mathrm{w}$ in this chapter refer to length, height and width of the representative types and $M, F$ to male and female specimens, respectively.

\section{Genus Bairdia M'Coy, 1844}

\section{Bairdia sp. 1}

(Pl. 1, fig. 2)

1978 Bairdia sp. 1, Khalifa \& Cronin: 174, pl.1, fig.9.

Material. About 140 carapaces and valves from the whole section.

$\begin{array}{llll}\text { Dimensions (mm). } & 1 & \mathrm{~h} & \mathrm{w} \\ & 1.25 & 0.80 & 0.64 \\ & 1.10 & 0.70 & 0.60 \\ & 1.08 & 0.68 & 0.59\end{array}$

Remarks. A typical species of the genus Bairdia, reported also from the Middle Eocene of Egypt (Khalifa \& Cronin, 1978). The surface of the carapace is entirely covered with small and dense pits. The eye-spot is oval and weakly developed. The valves are denticulated antero- and posteroventrally. Our specimens resemble in these features the figured type of Bairdia ilaroensis Reyment \& Reyment, 1959 in Bassiouni \& Luger (1990, p.780, pl.1, fig.15; Maastrichtian - Early Eocene of Egypt).

Genus Cytherella Jones, 1849

Cytherella cf. ventroconcava Neale \& Singh, 1985

(Pl. 1, fig. 1)

cf. 1985 Cytherella ventroconcava Neale \& Singh: 364 , pl.41, figs $10-12$.

Material. 45 carapaces and valves mostly from the middle part of the Sartaba Member.

Dimensions (mm).

$\begin{array}{lll}l & h & \text { w } \\ 0.82 & 0.47 & 0.38 \\ 0.85 & 0.51 & 0.44 \\ 0.82 & 0.47 & 0.36\end{array}$

Remarks. Our specimens with their concave ventral margin are very similar to those of Neal \& Singh (1985; Middle Eocene of Assam, India), but are definitely larger.

\section{Cytherella piacabucuensis Neufville, 1973}

(Pl. 1, fig. 3)

1973 Cytherella piacabucuensis Neufville: 137, pl.1, figs 3a-d. ?1978 Cytherella sp.1, Khalifa \& Cronin: 173, pl.1, fig.1. 1990 Cytherella piacabucuensis Neufville, Bassiouni \& Luger: 777, pl.l. figs 7-8, 10-11.

Material. Two carapaces from the sample CB 219.
Dimensions ( $\mathbf{m m})$.

$\begin{array}{lll}\text { l } & \text { h } & \text { w } \\ 0.61 & 0.32 & 0.24\end{array}$

Remarks. Cytherella piacabucuensis Neufville, 1973 was hitherto described in our region from Egypt (Bassiouni \& Luger,

\section{Explanation of Plate 1}

Fig. 1. Cytherella ef. ventroconcava Neale \& Singh, left valve, CB 213.

Fig.2. Bairdia sp. 1, right valve, CB 210.

Fig.3. Cytherella piacabucuensis Neufville, right valve, CB 219.

Fig.4. Cytherella sp., left valve, CB 200.

Fig.5. Paracypris sp. 1, left valve, CB 217.

Fig.6. Paracypris sp. 2, right valve, CB 212.

Fig.7. Xestoleheris kenawayi Khalifa \& Cronin, left valve, CB 217.

Fig.8. Xestoleheris kenawayi Khalifa \& Cronin, dorsal view, CB 215.

Fig.9. Bythocypris sp., Ieft valve, CB 215
Fig. 10. Parakrithe? sp., right valve, CB 212.

Fig.11. Soudanella gracilicosta Bassiouni, left valve, CB 211.

Fig.12. Buntonia ramosa Bassiouni, left valve, CB 219.

Fig.13. Buntonia cf. jordanica Bassiouni, right valve. CB 200.

Fig.14. Leguminocythereis hassani Khalifa \& Cronin, left valve, CB 207.

Fig.15. Leguminocythereis hassani Khalifa \& Cronin. right valve, CB 217. 


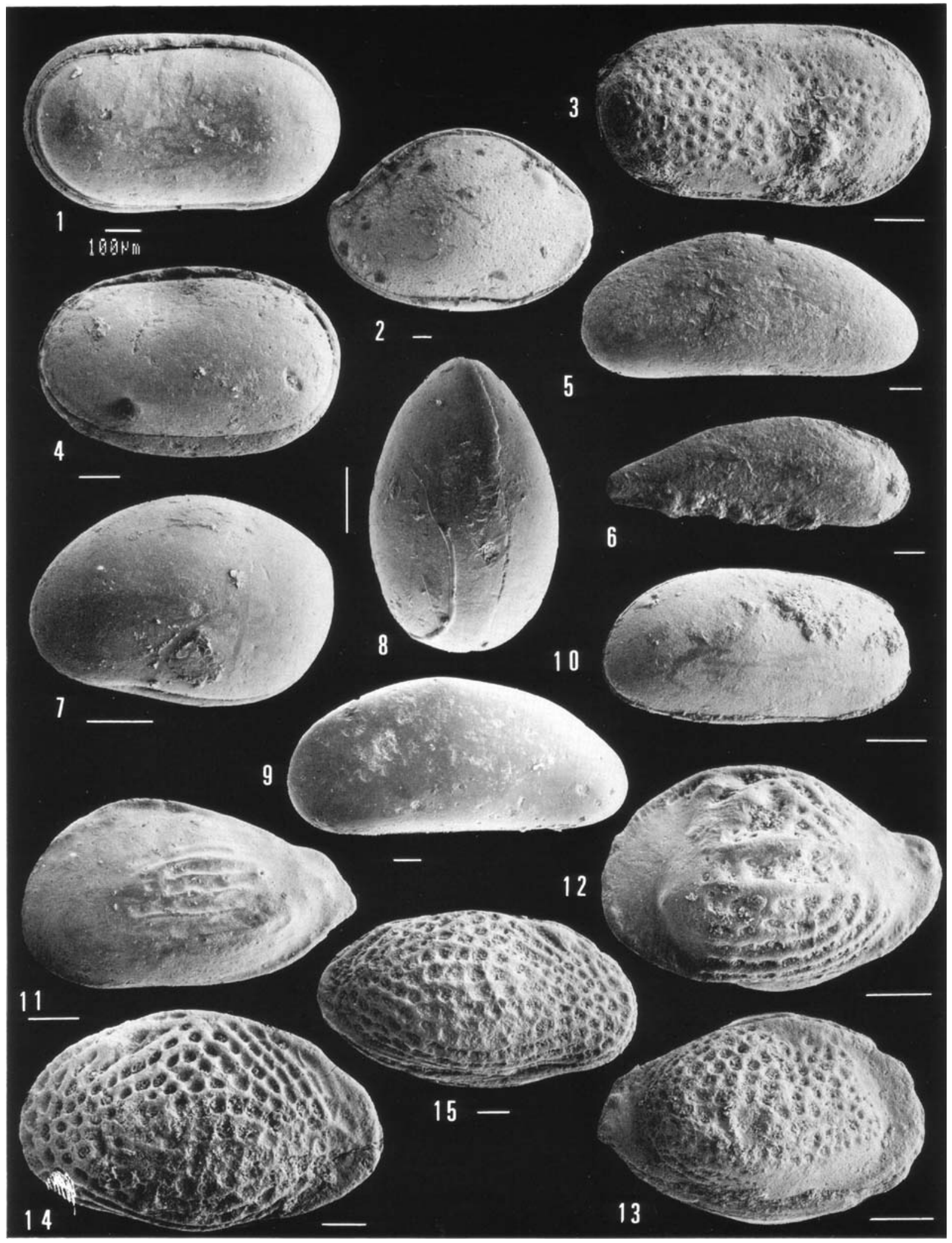


1990; Middle Paleocene - Early Eocene; Khalifa \& Cronin, 1978; Middle Eocene; Ismail A. and Szczechura, pers. comm., 1989; Middle Eocene).

\section{Cytherella sp.}

(PI. 1, fig. 4)

Material. About 130 carapaces and valves throughout the whole section.

$\begin{array}{llll}\text { Dimensions (mm). } & 1 & \text { h } & \text { w } \\ & 0.71 & 0.45 & 0.35 \\ & 0.81 & 0.51 & 0.37\end{array}$

Remarks. These common species of Cytherella exhibit no diagnostic features.

\section{Genus Paracypris Sars, 1866 \\ Paracypris sp.1 \\ (P1. 1, fig. 5)}

Material. 35 carapaces from the whole section.

$\begin{array}{llll}\text { Dimensions (mm). } & \text { I } & \text { h } & \text { w } \\ & 0.94 & 0.40 & 0.38 \\ & 0.81 & 0.34 & 0.33 \\ & 0.90 & 0.39 & 0.40\end{array}$

Remarks. Paracypris sp. 1 possesses a rounded posterior end.

\section{Paracypris sp.2}

(Pl. 1, fig. 6)

Material. 6 carapaces from the middle part of the section
Dimensions (mm).$$
1
$$$$
\text { h }
$$$$
\text { w }
$$$$
0.90
$$$$
0.26
$$$$
0.26
$$

Remarks. The posterior end of this species is pointed, terminating ventrally and differs mainly herein from Paracypris $\mathrm{sp} .1$.

$$
\begin{gathered}
\text { Genus Bythocypris Brady, } 1880 \\
\text { Bythocypris sp l. }
\end{gathered}
$$

(Pl. 1, fig. 9)

Material. 2 carapaces from the middle part of the section

$$
\begin{array}{llll}
\text { Dimensions (mm). } & \text { l } & \text { h } & \text { w } \\
& 1.20 & 0.50 & 0.45
\end{array}
$$

Remarks. A very large species of Bythocypris with rounded posterior and anterior ends.

\section{Genus Parakrithe Bold, 1958}

Parakrithe? sp.

(P1. 1, fig. 10)

Material. 15 carapaces from the middle and upper parts of the section.

$\begin{array}{llll}\text { Dimensions (mm). } & \mathrm{l} & \mathrm{h} & \mathrm{w} \\ & 0.51 & 0.28 & 0.21 \\ 0.51 & 0.25 & 0.22 \\ & 0.54 & 0.25 & 0.23\end{array}$

Remarks. The generic position of these specimens as species of Parakrithe must remain open, until single valves will be found and their marginal pore canals can be examined. The broadly rounded posterior end is characteristic for the small carapaces of Parakrithe? sp. Similar types of Parakrithe are also commonly found in Late Paleocene - Middle Eocene strata of Egypt (Cronin \& Khalifa, 1979; Bassiouni \& Luger, 1990; Ismail A. and Szczechura, pers. comm., 1989).

Genus Xestoleberis Sars, 1866

$$
\begin{gathered}
\text { Xestoleberis kenawayi Khalifa \& Cronin, } 1978 \\
\text { (Pl. 1, figs 7-8) }
\end{gathered}
$$

1978 Xestoleberis kenawayi Khalifa \& Cronin: 181 , pl. 1, figs 7-8 Material. About 180 valves and carapaces from the middle part of the section, abundant in samples CB 215 - CB 218.

$\begin{array}{llcr}\text { Dimensions (mm). } & \text { l } & \text { h } & \text { W } \\ & 0.44 & 0.32 & 0.30 \\ & 0.45 & 0.30 & 0.32 \\ 0.42 & 0.30 & 0.31\end{array}$

Remarks. This small form of Xestoleberis possesses a rounded anterior end, pointed ventrally, and shows an angular posterodorsal margin. The posterior margin is only slightly rounded to truncated. Xestoleberis kenawayi was described originally from the Middle Eocene sediments of Egypt (Khalifa \& Cronin, 1978). It differs from other Middle Eocene species of this genus mainly by its less rounded posterior end (X. subglubosa (Bosquet), 1852 in Boukhary et al., 1982b, pl.2, fig.11; and in Bassiouni et al., 1984, p.186, pl.2, fig.8). Our specimens are also very similar to X. kiseibaensis Bassiouni \& Luger, 1990 (p.848, pl.25, figs 8-12; Maastrichtian - Early Eocene of Egypt), but exhibits a less convex dorsal margin.

\section{Genus Soudanella Apostolescu, 1961}

Soudanella gracilicosta Bassiouni, 1969

$$
\text { (PI. 1, fig. 11) }
$$

1969 Soudanella gracilicosta Bassiouni (1969a): 210, pl.24, figs 9-10; pl.25, figs 5-8.

Material. 55 carapaces and valves throughout the section. Dimensions (mm).

$\begin{array}{llll}\text { l } & \text { h } & \text { w } & \\ 0.65 & 0.37 & 0.32 & \text { F } \\ 0.64 & 0.36 & 0.32 & \text { F }\end{array}$

\section{Explanation of Plate 2}

Fig. 1. Pterygocythereis sp., Ieft valve, CB 217.

Fig. 2. Pterygocythereis sp., dorsal view, CB 217.

Fig. 3. Cytheropteron boukharyi Khalifa \& Cronin, dorsal view, CB 218

Fig, 4. Acanthocythereis? sp., left valve, CB 218 .

Fig. 5. Ordoniya hasaensis (Bassiouni), left valve, CB 219

Fig. 6. Brachycythere (Digmocythere) ismaili Bassiouni, right valve, CB 217].

Fig. 7. Reticulina proteros Bassiouni, left valve, CB 211 .

Fig. 8. Reticulina praescitula Bassiouni, left valve, CB 207.
Fig. 9. Reymenticosta crassireticulata crassireficulata (Bassiouni), right valve, CB 215.

Fig.10. Reymenticosta crassireticulata crassireticulata (Bassiouni), dorsal view, CB 205.

Fig.11. Megommatocythere cf. denticulata (Esker), left valve, CB 210.

Fig.12. Megommatocythere cf denticulata (Esker), left valve. CB 210.

Fig.13. Revmenticosta varmukensis (Bassiouni), left valve. CB 207. 


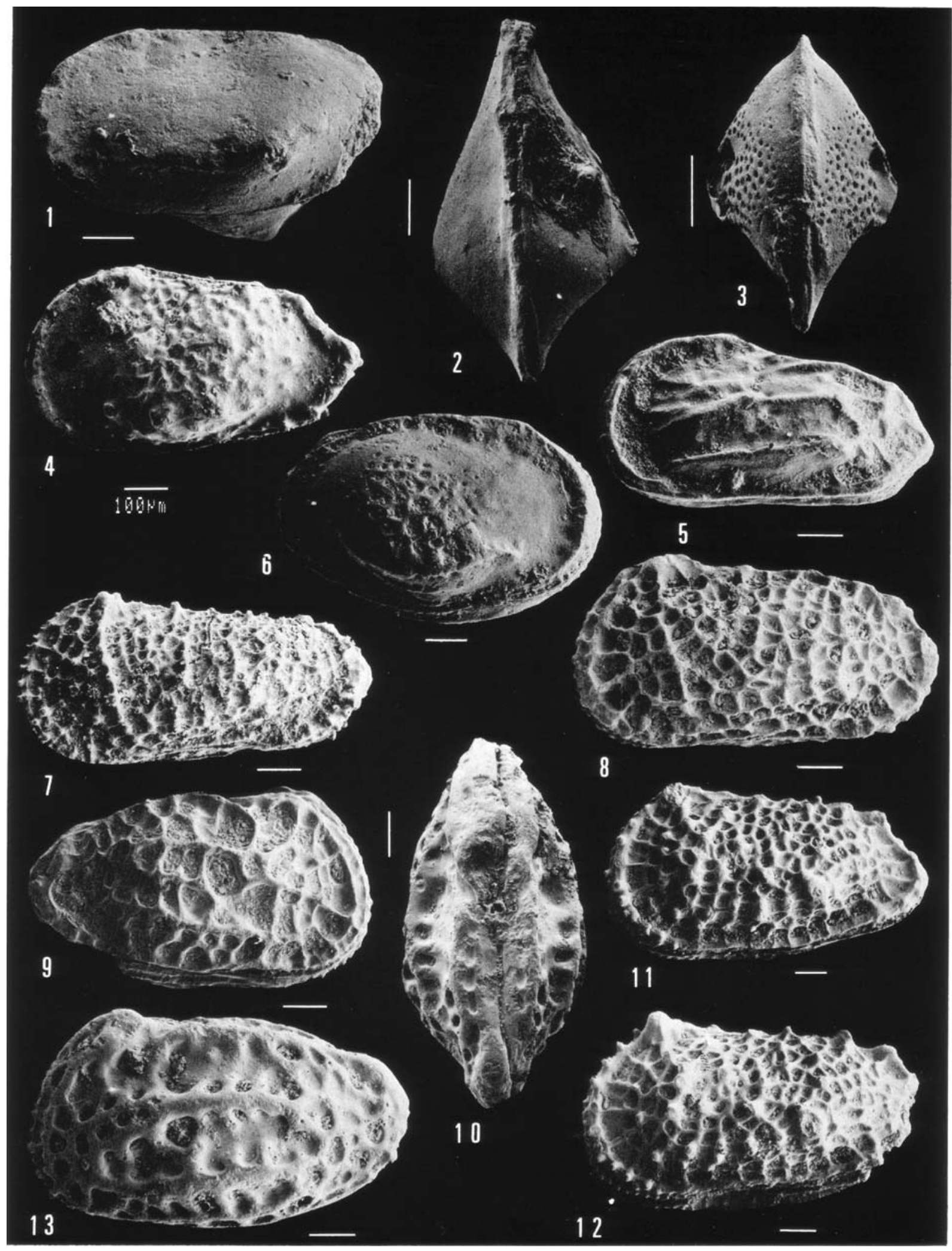




$$
\begin{array}{llll}
0.66 & 0.34 & 0.26 & M
\end{array}
$$

Remarks. Our specimens with their $4-5$ ribs in the central area are identical with the type species, described from the Middle-Late Eocene of Jordan (Bassiouni, 1969a). This species exhibits in other sections in Israel a relatively broad stratigraphic range, but is most common here in this Early - Middle Eocene transition interval.

\section{Genus Buntonia Howe, 1965}

Buntonia ramosa Bassiouni, 1969

$$
\text { (Pl. 1, fig. 12) }
$$

1969 Buntonia ramosa Bassiouni (1969a): 207, pl.24, figs 1-4

Material. 5 carapaces from the middle part of the section.

Dimensions (mm).

$\begin{array}{llll}\text { l } & \text { h } & \text { W } & \\ 0.51 & 0.33 & 0.33 & \text { F } \\ 0.55 & 0.34 & 0.28 & \text { M } \\ 0.50 & 0.31 & 0.30 & \text { F }\end{array}$

Remarks. Buntonia ramosa occurs in Israel in a similar stratigraphic level as in Jordan (Bassiouni, 1969a; Middle Eocene).

\section{Buntonia cf. jordanica Bassiouni, 1969}

(Pl. 1, fig. 13)

cf. 1969 Buntonia jordanica Bassiouni (1969a): 206, pl.24, figs

5-6); pl.25, figs $1-4$

Material. 4 carapaces from the lower and middle part of the section.

$\begin{array}{lllll}\text { Dimensions (mm). } & \mathrm{l} & \mathrm{h} & \mathrm{w} & \\ & 0.59 & 0.30 & 0.24 & \mathrm{M} \\ & 0.53 & 0.30 & 0.29 & \mathrm{~F}\end{array}$

Remarks. The specimens of Buntonia cf, jordanica from the Sartaba section are very similar to the type material from Jordan (Bassiouni, 1 969a, Middle Eocene), but are smaller and less regularly reticulated.

Genus Leguminocythereis Howe, 1936

Leguminocythereis hassani Khalifa \& Cronin, 1978

(P1.1, figs 14-15)
1978 Leguminocythereis hassani Khalifa \& Cronin: 178, pl.2, figs $1-2$.

Material. 5 carapaces and 1 left valve from the lower and middle part of the Sartaba section

Dimensions (mm).

$\begin{array}{llll}\text { l } & \text { h } & \text { W } & \\ 0.81 & 0.48 & 0.42 & \text { F } \\ 0.76 & 0.48 & 0.43 & \text { F } \\ 0.92 & 0.50 & 0.49 & \text { M }\end{array}$

Remarks. Leguminocythereis hassani with a distinct sexual dimorphism is relatively rare in the Sartaba section, but occurs also in Middle Eocene beds of Egypt (Khalifa \& Cronin, 1978).

Genus Pterygocythereis Blake, 1933

Pterygocythereis sp.

(Pl. 2, figs 1-2)

Material. 8 carapaces from the middle part of the section. Dimensions ( $\mathbf{m m})$.

$\begin{array}{lll}l & h & w \\ 0.63 & 0.34 & 0.39 \\ 0.66 & 0.36 & 0.34 \\ 0.66 & 0.35 & 0.38\end{array}$

Remarks. Our specimens are badly preserved, but show a very faint reticulation. A dorsomedian sulcus exists, the ventral ala is pointed at $2 / 3$ length of the carapace. The posterior end is pointed subdorsally.

\section{Genus Cytheropteron Sars, 1866}

Cytheropteron boukharyi Khalifa \& Cronin, 1978

$$
\text { (PI. 2, fig. 3) }
$$

Material. 1 carapace from sample CB 218.

$\begin{array}{llll}\text { Dimensions (mm). } & \text { I } & \text { h } & \text { w } \\ & 0.45 & 0.22 & 0.30\end{array}$

Remarks. The carapace of this species is finely punctated. Our single specimen is smaller than the type-species, described by Khalifa \& Cronin (1978) from the Middle Eocene of Egypt.

Genus Acanthocythereis Howe, 1963

\section{Explanation of Plate 3}

If not otherwise indicated, the scale on Fig. 3 implies for all Figures.

Fig. 1. Acarinina sp., spiral view, CB 218 (scale $=50$ microns).

Fig. 2. Acarinina sp., axial view, CB 218 (scale $=50$ microns).

Fig. 3. Truncorotaloides rohri Broennimann \& Bermudez, spiral view, CB 218 (scale $=100$ microns).

Fig. 4. Truncorotaloides rohri Broennimann \& Bermudez, umbilical view, CB 218 .

Fig. 5. Truncorotaloides rohri Broennimann \& Bermudez, axial view, CB 218.

Fig. 6. Acarinina aspensis (Colom), spiral view, CB 218.

Fig. 7. Acarinina broedermanni (Cushman \& Bermudez), spiral view, CB 212.

Fig. 8. Guembelitriodes higginsi (Bolli) (low spired), axial view, CB 218.

Fig. 9. Guembelitriodes higginsi (Bolli) (high spired), axial view, CB 218

Fig.10. "Globigerina" sp, spiral view, CB 218.

Fig. 11. "Globigerina" sp., umbilical view, CB 218.

Fig. 12. "Globigerina" sp., axial view, CB 218.
Fig. 13. Morozovella spinulosa (Cushman) (early form) spiral view, CB 215.

Fig. 14. Subbotina inaequispira (Subbotina), spiral view, CB 218.

Fig. 15. Subbotina inaequispira (Subbotina), axial view, CB 218.

Fig. 16. Subbotina kierstedae Fleisher "Sphaeroidinellopsis" senni (Beckmann), spiral view, CB 211.

Fig. 17. Subbotina kierstedae Fleisher "Sphaeroidinellopsis" senni (Beckmann), umbilical view, CB 211.

Fig. 18. Subbotina kierstedae Fleisher"Sphaeroidinellopsis" senni (Beckmann), axial view, CB 211.

Fig. 19. Turbotalia cerroazulensis possagnoensis (Toumarkine \& Bolli), spiral view, CB 218.

Fig. 20. Turbororalia cerroazulensis possagnoensis (Toumarkine \& Bolli), axial view. CB 211.

Fig. 21. Turborotalia cf. cerroazulensis pomeroli (Toumarkine \& Bolli), axial view, CB 218.

Fig. 22. Hantkenina muttalli Toumarkine, lateral view, CB 215. 


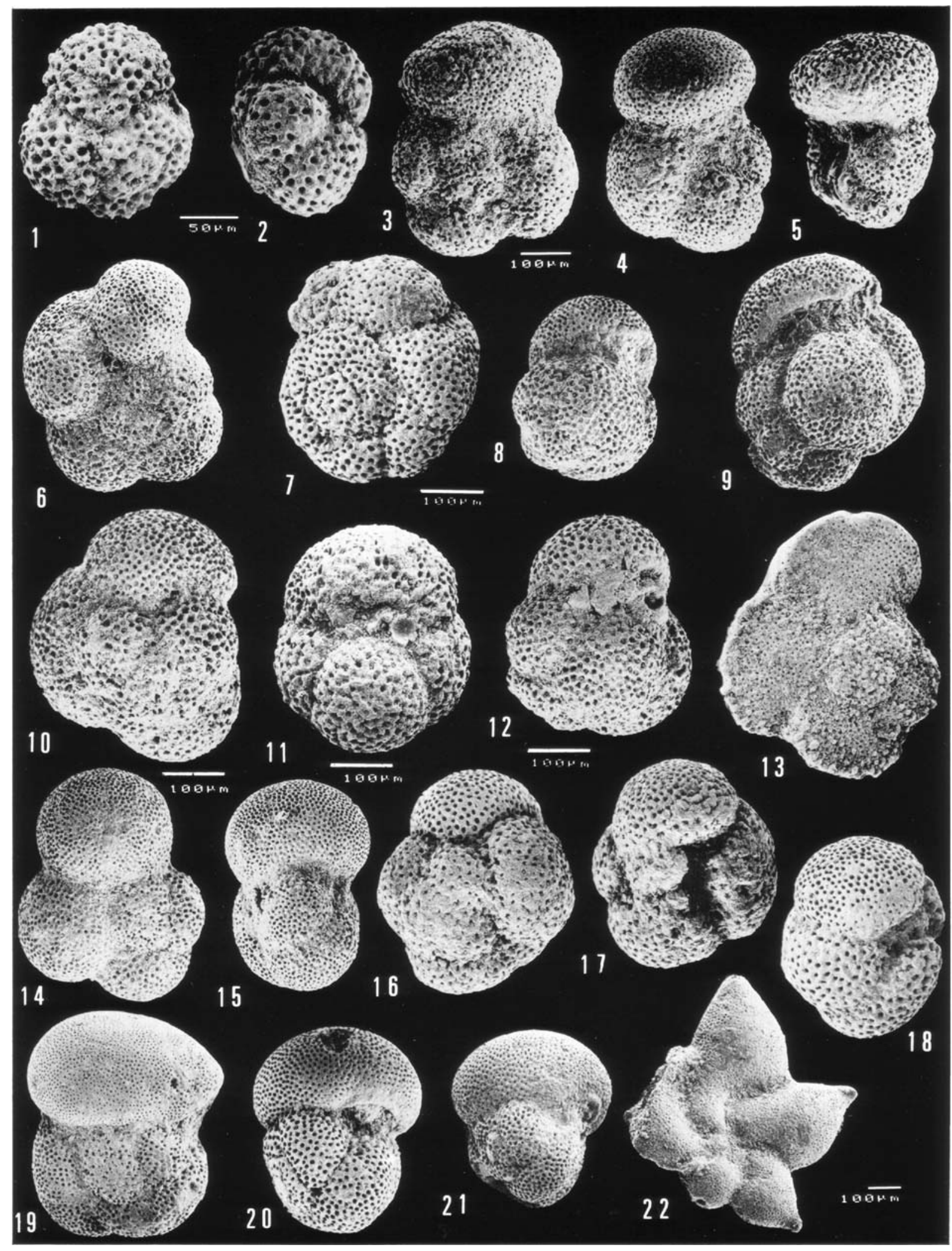


Acanthocythereis? sp.

(Pl. 2, fig. 4)

Material. 3 carapaces from CB 212 and CB 218 .

$\begin{array}{llll}\text { Dimensions (mm). } & 1 & \text { h } & \text { w } \\ & 0.80 & 0.42 & 0.33 \\ & 0.80 & 0.42 & 0.37\end{array}$

Remarks. The rare occurrence of this species in the Sartaba section and the lack of information of its internal features do not allow its final definition as a probably new species of the genus Acanthocythereis. The specimens are finely reticulated, mostly in their central area, and possess low tubercles. The anterior and posterior areas are smooth. A ventral rib is composed of a chain of small nodes.

Genus Brachycythere Alexander, 1933

Subgenus Digmocythere Mandelstam, 1958

Brachycythere (Digmocythere) ismaili Bassiouni, 1971

(PI. 2, fig. 6)

1971 Brachycythere (Digmocythere) ismaili Bassiouni (1971a): 170, pl.7, figs 5-6.

1974 Brachycythere (Digmocythere) ismaili Bassiouni, Bassiouni et al.: 184, pl.2, figs 1a-c.

Material. 2 carapaces from the middle part of the section.

$\begin{array}{lllll}\text { Dimensions (mm). } & \text { l } & \text { h } & \text { w } & \\ & 0.77 & 0.50 & 0.42 & \text { F }\end{array}$

Remarks. This species shows a prominent ventrolateral convexed ventral rib. The central zone is coarsely pitted. A distinct rim is developed anteriorly and dorsally. B. (D). ismaili was reported from Egypt from Middle Eocene (Bassiouni et al., 1984) and Late Eocene sediments (Bassiouni, 1971a).

Genus Ordoniya Al-Sheikhly, 1985

Ordoniya hasaensis (Bassiouni), 1971 (Pl. 2, fig. 5)

1971 Hazelina hasaensis Bassiouni (1971b): 33, pl.5, figs 5-6.

Material. 3 carapaces from the upper part of the Sartaba Member. Dimensions (mm).

$\begin{array}{lll}\text { l } & \text { h } & \text { w } \\ 0.80 & 0.40 & 0.32 \\ 0.80 & 0.41 & 0.32\end{array}$

Remarks. The size, shape and rib pattern of our specimens agree well with the type-species and justify its definition as Ordoniya hasaensis. The range of this species, originally described from the Late Paleocene - Early Eocene of Jordan (Bassiouni, 1971b) is here extended to the early Middle Eocene. This species is found in Egypt in Early Eocene sediments (Ismail A. and Szczechura, pers. comm., 1989).

Genus Reticulina Bassiouni, 1969

Reticulina proteros Bassiouni, 1969

(P1. 2, fig. 7)

1969 Carinocythereis (Reticulina) scitula proteros Bassiouni (1 969b): 11, pl.1, fig.8; pl.2, Figs 6, 7.

1982 Reticulina proteros Bassiouni, Donze et al.: 287, pl.5, figs 78

1990 Reticulina proteros Bassiouni, Bassiouni \& Luger: 836, pl.20, figs 16-21,
Material. 2 carapaces from the upper part of the Sartaba Member Dimensions (mm).

$\begin{array}{llll}\text { l } & \text { h } & \text { w } & \\ 0.85 & 0.38 & 0.31 & \text { M } \\ 0.38 & 0.40 & 0.40 & \text { F }\end{array}$

Remarks. Reticulina with fine reticulation. Many small spines occur on the junction of reticulation ribs. A transversal oblique distinct ridge, mainly built by tubercles, starts from the very prominent eye spot and continues towards the ventral margin. Reticulina proteros was hitherto recorded only from Late Paleocene - Early Eocene sediments of Jordan (Bassiouni, 1 969b), Egypt (Bassiouni \& Luger, 1990) and Tunisia (Donze et al., 1982). The figured specimens from Tunisia are less spinous than our material.

\section{Reticulina praescitula Bassiouni, 1969 \\ (Pl. 2, fig. 8)}

1969 Carinocythereis (Reticulina) scitula praescitula Bassiouni ( 1 969b): 13 , pl.2, fig.5.

1969 Carinocythereis (Reticulina) scitula ssp., Bassiouni (1969c): 398 , pl.26, fig.4.

Material. 80 carapaces and valves from most of the samples of the section.

$\begin{array}{lllll}\text { Dimensions (mm). } & \text { l } & \text { h } & \text { w } & \\ & 0.83 & 0.48 & 0.40 & \text { F } \\ & 0.85 & 0.45 & 0.40 & \text { F } \\ & 0.85 & 0.41 & 0.34 & \text { M }\end{array}$

Remarks. Reticulina praescitula is similar to $R$. proteros, but differs from it by its less spinous ornamentation, less prominent eye-spot, coarser reticulation and the more developed longitudinal riblets. This species was found in Middle Eocene strata of Jordan (Bassiouni, 1969b) and Egypt (Bassiouni, 1969c; Ismail A. \& Szczechura, pers. comm., 1989).

\section{Genus Reymenticosta Bassiouni \& Luger, 1990}

Reymenticosta crassireticulata crassireticulata (Bassiouni), 1969

(P1. 2, figs 9-10)

1969 Costa crassireticulata Bassiouni (1969b): 403, pl.28, figs $2-$ 5.

1979 Costa bassiounii Cronin \& Khalifa: 402, pl.2, figs 16-18.

1982 Costa crassireticulata Bassiouni, Boukhari et al. (1982b): 57, pl.2, figs 6a-b.

Material. 22 carapaces and 3 valves from the lower and middle part of the section.

Dimensions (mm).

$\begin{array}{lll}1 & \text { h } & \text { w } \\ 0.80 & 0.43 & 0.43 \\ 0.72 & 0.43 & 0.36\end{array}$

Remarks. Costa crassireticulata crassireticuiata (see Bassiouni et al., 1984) is included hereby in the genus Reymenticosta Bassiouni \& Luger, 1990 because of its more oval, Veenia like outline. This species is also found in the Middle Eocene of Jordan (Bassiouni, 1969b) and Egypt (Cronin \& Khalifa, 1979; Boukhary et al., 1982b). The juveniles show a denser reticulation pattern in the anterior area than in the adult forms.

Reymenticosta yarmukensis (Bassiouni), 1969

(P1. 2, fig. 13)

Costa? yarmukensis Bassiouni (1969c), p.7, pl.2, figs 1-2

Material. 30 carapaces and valves from the lower and middle part 
Dimensions (mm).

$\begin{array}{cll}\text { of the section. } & \\ 1 & \mathrm{~h} & \mathrm{w} \\ 0.90 & 0.50 & 0.48 \\ 0.92 & 0.48 & 0.49 \\ 0.90 & 0.45 & 0.43 \\ 0.83 & 0.48 & 0.45\end{array}$

Remarks. Reymenticosta yarmukensis (Bassiouni, 1969c; Middle Eocene of Jordan) is similar to $R$. crassireticulata crassireticulata (Bassiouni, 1969b), but differs from the latter mainly by its broader ribs and coarser reticulation.

Genus Megommatocythere Colin \& Oertli, 1982 (in Donze et al., 1982)

Megommatocythere cf. denticulata (Esker), 1968

(P1.2, figs 11-12)

cf. 1966 Acanthocythereis sp., Salahi: 22, pl.5, fig.27.

cf. 1968 Acanthocythereis denticulata Esker: 328, pl.2, figs 6-7; pl.4, fig. 1 .

cf. 1982 Acanthocythereis? denticulata Esker, Donze et al.:293, pl.11, figs 1-4.

cf. 1990 Megommatocythere denticulata (Esker), Bassiouni \& Luger: 825 , pl.17, fig.7.

Material. 3 carapaces from the middle part of the section. Dimensions (mm).

$\begin{array}{lll}\text { l } & \text { h } & \text { w } \\ 0.87 & 0.48 & 0.48 \\ 0.88 & 0.49 & 0.49\end{array}$

Remarks. The type species of Megommatocythere denticulata from the Paleocene of Tunisia (Esker, 1968), as well as the figured specimen of Salahi (1966) from the Early Eocene of Libya are more spinous than our specimens. Specimens of this species with less prominent and fewer tubercles are reported from the Late Maastrichtian - Paleocene of Tunisia (Donze et al., 1982) and the Paleocene of Egypt (Bassiouni \& Luger, 1990) and agree rather well with our material. However, all hitherto described species are definitely larger than $M$. cf. denticulata.

\section{PLANKTONIC FORAMINIFERA}

\section{(C. Benjamini)}

Well-preserved microfaunas were recovered from samples CB 207 - 218, from the middle chalky part of the unit. Chalk from between the limestone interbeds contained recrystallized material from which only benthic foraminifera were recovered. Nomenclature of the planktonic foraminifera follows that of Benjamini (1980), for similar intervals in the northern Negev, and generally, usage in Toumarkine \& Luterbacher (1985). Fig.3 shows the distrubution of the planktonic foraminifera in the chalky lithofacies of the Sartaba Member. Some of the species are illustrated on Pl 3.

The following species are common at Qeren Sartaba. Only a brief discussion of special features is here presented. These are included to clarify our biostratigraphic conclusions.

Acarinina aspensis (Colom)/pentacamerata (Subbotina) [P1.3, fig.6].

Benjamini (1980) ranged these two forms together. In the Qeren Sartaba material. The A. aspensis morphotype is clearly dominant.
Acarinina broedermanni (Cushamn \& Bermudez) [P1.3, fig.7].

Acarinina bullbrooki (Bolli) (gp.) [not illustrated]. Several morphotypes are included here, including $A$. matthewsae Blow.

Acarinina soldadoensis (Broennimann) (gp.) [not illustrated]

The last members of this group are found in the lower samples of the interval.

Acarinina spinuloinflata (Bandy) [not illustrated].

Acarinina sp. [P1.3, figs 1-2].

This very small form superficially resembles $A$. spinuloinflata, but the aperture is nearly in a globigerinid position and it is very spinose. It may be more closely related to $A$. broedermanni. It was also found in the Negev.

"Globigerina": sp. [P1.3, figs 10-12]

The affinity of this species is highly problematic. It has a subspherical test, and unlike "Sphaeroidinellopsis" senni, has a clearly defined, rather high early trochospire. In that respect its closest affinities are to some Globigerinatheka, but does not have an embrancing final chamber or bulla. The spire, test shape, and position of the single aperture strongly suggest affinity with Globigerinatheka index (Finlay) (gp.). It cannot be placed there as it lacks the requirements of that genus, but seems to be ancestral to that group.

Guembelitriodes higginsi (Bolli) (high spired) [P1.3, fig.9].

Guembelitriodes higginsi (Bolli) (low spired) [P1.3, fig.8].

Benjamini (1980) demonstrated an evolutionary succession from a Subbotina ancestor through a low spired morphotype to the high spire of the end member. Other authors prefer to derive $G$. higginsi from Globigerina lozanoi Colom (cf. Toumarkine \& Luterbacher, 1985).

Hantkenina nuttalli Toumarkine [P1.3, fig.22].

Morozovella aragonensis (Nuttall) [not illustrated].

Morozovella spinulosa (Cushman) (early form, close to $A$. bullbrook; [P1.3, fig.13].

These are the transitional forms from $A$. bullbrook to $M$. spinulosa. We do not differentiate $M$. crassata densa (Cushman).

Morozovella spinulosa (Cushman) (biconvex) [not illustrated].

Pseudohastigerina micra (Cole) [not illustrated].

Subbotina kierstedae (Fleisher) I"Sphaeroidinellopsis" senni (Beckmann) [P1.3, fig.16-18].

The forms present at Qeren Sartaba still have a fairly open umbilicus and do not have the sphaeroidal form of the "S." senni end member. The crust is well developed and the form is not a Subbotina.

Subbotina inaequispira (Subbotina) [P1.3, figs 14-15]. Many variants belonging to the $\mathrm{S}$. inaequispira. 


\section{"Hastigerina" cf. bolivinaria "Turborotalia" griffinae plexus are found at Sartaba.}

Truncorotaloides rohri Broennimann \& Bermudez [P1.3, figs.3$5]$.

Turborotalia cerroazulensis frontosa (Subbotina) [not illustrated].

Turborotalia cerroazulensis possagnoensis (Toumarkine \& Bolli) [P1.3, figs 19-20].

Turborotalia cf. cerroazulensis pomeroli (Toumarkine \& Bolli)[P1.3, fig.21].

\section{BIOSTRATIGRAPHIC CORRELATION}

The Sartaba Member of the Matred Formation at Qeren Sartaba spans the Early - Middle Eocene transition. The lower chalk interval of the Sartaba Member may be correlated, therefore, to the Horsha Formation and the base of the Matred Formation (s.s.) of the northern Negev, according to the biostratigraphic scheme of Benjamini (1980). The relevant standard zonal schemes are as follows:

1. The Sphaeroidinellopsis senni Zone (latest Early Eocene). Benjamini (1980) erected the Sphaeroidinellopsis senni Zone for the upper part of Zone P9 (Blow, 1979) pentacamerata zone (Krasheninnikov, 1965), subsequent to the extinction of Planorotalites palmerae. The top of the range of the Acarinina soldadoensis group extends into this zone, while the first appearance datum of Turborotalia cerroazulensis frontosa is near its base. Samples CB 200 - 214 of the Qeren Sartaba section belong to this zone. Many authors (see discussion in Blow, 1979 and in Toumarkine \& Luterbacher, 1985) consider the upper part of this zone to belong to the Middle Eocene, as many Middle Eocene forms develop during this interval, but the presence of Hantkenina nuttalli in the Sartaba section, and in the northern Negev in the same interval, clearly defines only the overlying zone as the base of the Middle Eocene.

2. The Hantkenina nuttalli Zone (earliest Middle Eocene; Bolli, 1957, subsequently renamed, see discussion in Toumarkine \& Luterbacher, 1985). This is the zone P10 of Blow (1979). The nominate species defines the base of the Middle Eocene. This zone extends to the first appearance of Globigerinatheka subconglobata subconglobata. The latter does not appear in the Qeren Sartaba material, but is common in the northern Negev in somewhat younger strata. We therefore conclude that samples CB $215-218$ of the Qeren Sartaba section belong to the $H$. nuttalli Zone. The uppermost sample contains a form close to Turborotalia cerroazulensis pomeroli, indicating proximity to the overlying zone

\section{CONCLUSIONS}

All 23 ostracod species, which occur in the Sartaba section, are known from the literature and are described from the Middle East, defining an Early - Middle Eocene age for these strata. Eight of them belong mostly to smooth and stratigraphically not important species and are left in open nomenclature. The Sartaba Member of the Matred Formation at Qeren Sartaba cannot be subdivided by means of ostracods. Reticulina praescitula, Bairdia sp.1, Cytherella cf. ventroconcava, Xestoleberis kenawayi and Soudanella gracilicosta are the most common ostracod species in this section.

The sometimes abundant occurrence of euryhaline inner to outer shelf specimens of Xestoleberis kenawayi in the middle part of the section points to a shallowing event within an otherwise normal marine outer shelf environment during the deposition of most of the section. The planktonic foraminifera present at Qeren Sartaba clearly place this section across the Early - Middle Eocene transition, based on the first appearance of Hantkenina nuttalli. The upprmost horizons which could be clearly dated are placed at the top of Zone P10. Benthic foraminifera of Midwayan aspect place water depths at outer shelf, 50-150m deep. Hardground horizons and sporadic larger benthic foraminifera indicate periodic shallowing to within the shallower parts of this range.

\section{ACKNOWLEDGEMENTS}

The authors wish to thank Dr Janina Szczechura and Ismail A., Institute of Paleobiology, Polish Academy of Sciences, Warszaw, for their kind permission to compare unpublished material on Eocene ostracods of Egypt and critical reading of the manuscript. Thanks are also due to Dr Q. Siddiqui, Saint Mary University, Halifax, Canada, for many helpful suggestions. Technical support for this paper was provided by M. Dvorachek and Y. Levy, Geological Survey of Israel, Jerusalem. The grants of the Ministry of Energy and Infrastructure, Earth Sciences Research Administration, No.87-200-257 to A.H. and A.R. and in part, No.88-200-285 to C.B. are gratefully acknowledged.

\section{REFERENCES}

Al-Furaih, A.A.F. 1983. Paleocene and Lower Eocene Ostracoda from the Umm er Radhuma Formation of:Saudi-Arabia, Univ. Kansas, Paleont. Contrib. 107, 1-6.

Bassiouni, M.A.A. 1969a. Einige Buntonia- und Soudanella-Arten (Ostracoda, Crustac.) aus dem Eozaen von Jordaanien. Palaeont. Zeitschr., 43, 205-214.

Bassiouni, M.A.A. 1969b. Ostracoden aus dem Eozaen von Aegypten. 1. Trachyleberidinae. Geol. $\mathrm{Jb}, \mathbf{8 7}, 383-426$.

Bassiouni, M.A.A. 1969c. Einge Costa- und Carinocythereis (Reticulina)-Arten aus dem Palaeozaen und Eozaen von Jordanien (Ostracoda). N. Jb. Geol. Paleont., Abh., 34, 1-16.

Bassiouni, M.A.A. 1 969d. Ostracoden aus dem Eosaen von Aegypten. 2. Die Unterfamilien Hemicytherinae, Thaerocytherinac und Camplocytherinae. Geol. Jb. 88., 203-234.

Bassiouni, M.A.A. 1971 a. Ostracoden aus dem Eozean von Aegypten. 3. Die Unterfamilien Brachycytherinae und Buntoniinae. Geol. Jh., 89, 169-192.

Bassiouni, M.A.A. 1971 b. Ostracoda (Mauritsininae und Trachyleberidinae) und ihre Bedeutung fuer die Biostratigraphie des Mastricht und des Alttertiaer von Jordanien. Geol. Jb., Beih., 106, 5-52.

Bassiouni, M.A.A., Boukhary, M., Shama, K.\& Blondeau, A. 1984. Middle Ecocene ostracodes from Fayoum, Egypt. Geol. Mediterr., 11, 181-192.

Bassiouni, M.A. A. \& Luger, P. 1990. Maastrichtian to Early Eocene ostracoda from southern Egypt. Paleontology, palaeoecology, palaeobiogeography and biostratigraphy. Berliner Geowiss. Abh., (A), 120 (2), 755-928

Benjamini, C. 1973. The stratigraphy and structural geology of the Sartaba area, Samaria. Unpub. M.Sc. thesis, Hebrew Univ., Jerusalem, 1-100.

Benjamini, C. 1980. Planktonic foraminiferal biostratigraphy of the Avedat Group (Eocene) in the northern Negev, Israel. J. Paleont., 54, 325-358.

Blow, W.H. 1979. the Cainozoic Globigerinida. 3 vols. 1413p., Brill, Leiden.

Boukhary, M.A., Guernet, C. \& Mansour, H. 1982 (Boukhary et al., 1982a) Ostracodes du Tertiaire inferieur de l'Egypte Cah Micropal , 1, 13-20

Boukhary, M.A. Toumarkine, M., Khalifa, H. \& Arif, M. (Boukhary et al., $1982 b$ ). Etude biostratigraphique a l'aide des foraminiferes planctoniques et des ostracodes de l'Eocene de Beni Mazar, Vallee du Nil, Egypte. Cah. Micropal., I, 53-64. 
Ostracods and foraminifera from the Early - Middle Eocene of Qeren Sartaba, Jordan Valley

Cronin, T.M. \& Khalifa. H. 1979. Middle and Lare Eocene ostracoda from Gebel el Mereir, Nile Valley, Egypt. Micropaleomology, 4, 397-411.

Donze, P., Colin, J.P., Damotte, R., Oertli. H.J. Peypouquet, J.P. \& Said. R. 1982. Les ostracodes du Campanien teminal a l'Eocene inferieur de la coupe de Kef', Tunisie nordoccidental. Bull. Centre Rech. Explor.-Prod. Elf-Aquitame. 6. 273 335.

Esker. G.C. 1968. Danian ostracodes from Tunisia. Micropaleontology, 14. $319-333$.

Khalifa, H. \& Cronin, T.M. 1978. Ostracodes de l'Eocene moyen de el Sheikh FadI. est der Beni Mazar, Haute-Egypte. Rev. Micropaleont. 22, 172-185.

Krasheninnikov, V.A. 1965. Zonal stratigraphy of paleogene deposits. 21st. International Geological Congress, Norden.

Mimran, Y. 1984. Unconformities on the eastem tlank of the Fari a Anticline and their implications on the structural evolution of Samaria (Central 1srael). I.s\%. I Earth-Sci., 33, 1-11.

Neale, J.W. \& Singh, P. 1985. Ostracoda from the Middle Eocene of Assam. Palaeontology, 28, 355-385.

Salahi, D. 1966. Ostracodes du Cretacé supériour et du Tértaire en provenence d'un sondage de la région de Zelten (Libye). Rev'. Inst. Franc. Pétrol. 21, 3-43.

Toumarkine, M. \& Luterbacher, H.P. 1985. Paleocene and Eocene planktic foraminifera. In:Bolli, H.M. \& Perch-Nielsen, K. (eds), Plankton Stratigraphy. 87-154, Cambridge University Press, Cambridge. 